\title{
A Review of Capital Budgeting Techniques
}

\author{
Oluseun Paseda, Ph.D. \\ Department of Banking and Finance \\ University of Ibadan, Nigeria
}

Received: Nov. 2, 2020

Accepted: Nov. 27, 2020

Published: Dec. 5, 2020

doi:10.5296/iss.v8i2.18034

URL: https:// doi.org/10.5296/iss.v8i2.18034

\begin{abstract}
Perhaps the single most important decision faced by management is the selection of investment projects that maximize the present value of shareholders' wealth. This paper is a review of the literature on capital budgeting procedures. Analytic techniques such as Net present value (NPV), Internal rate of return (IRR), Payback, Discounted Payback, Time-adjusted discounting, Accounting Rate of Return, Profitability Index and Modified IRR are reviewed here. Additional supplementary techniques, when some complexities relating to risk and uncertainty are involved, are also discussed. Results of field surveys are reported. In sum, the results suggest increased prominence of the NPV as an evaluation technique consistent with its much emphasized academic merit. In particular, the Graham and Harvey (2001) survey reveals that the likelihood of using specific evaluation techniques is linked to three factors namely firm size, firm leverage and CEO characteristics. The study recommends the use of real options techniques as they facilitate the linkage of financial objectives with corporate strategy in the ever-increasingly complex business environment.
\end{abstract}

Keywords: Capital budgeting, Net present value, Value maximization, Real options 


\section{Mll Macrothink}

\section{Introduction}

The investment decision is essentially how much not to consume in the present in order that more can be consumed in the future. It involves the commitment of resources today in expectation of greater future benefits. The optimal investment decision maximizes the expected satisfaction (expected utility) gained from consumption over the planning horizon of the decision maker (Fama \& Miller, 1972). We assume that all economic decisions ultimately reduce to questions about consumption. More fundamentally, consumption is related to survival.

The consumption/investment decision is important to all sectors of the economy. An individual who saves does so because the expected benefit of future consumption provided by an extra amount of savings exceeds the benefit of consumption spending today. Corporate managers, acting as agents for shareholders, must decide between paying out earnings in the form of dividends, which may be used for present consumption, and retaining the earnings to invest in productive opportunities that are expected to yield future consumption. Managers of not-for-profit organizations try to maximize the expected utility of contributors - those individuals who provide external funds. And public sector managers try to maximize the expected utility of their constituencies.

The investment decisions reviewed and discussed here relate to incorporated companies but, the decision criterion which is to maximize the present value of lifetime consumption, can be applied to any sector of the economy (Akintola-Bello, 1977, Okafor, 1983, Elumilade, Asaolu \& Ologunde, 2006).

There are various forms of investment or capital projects, e.g., the setting up of a subsidiary firm, the building of a new office or factory block, the purchase of new machinery or equipment. Each of these projects normally requires the commitment of a substantial outlay of funds over a fairly long period of time. Those projects whose final benefits are expected to accrue within one fiscal period are assumed to be current outlays, while those whose benefits accrue beyond one fiscal period are termed capital outlays. It is these capital outlays that are amenable to project evaluation procedure (Okafor, 1983, p. 203).

Generally, investors face projects evaluation situations when they contemplate establishment of new projects, and the expansion and/or modernization of existing facilities. Other situations are considerations relating to asset replacement, plant capacity, lease or buy, make or buy and debt refunding decisions.

\section{Nature of Capital Budgeting Decisions}

The impression is often created that project evaluation starts and ends with cost-benefit analysis. Such an impression is rather erroneous. Apart from cost-benefit (financial) analysis, the engineering, production, marketing and management implications of a project must be considered. In broad terms, project analysis requires three forms of inter-related investigations - technical (engineering) analysis, economic analysis and financial (profitability) analysis (Akintola- Bello, 1977, Okafor, 1983, Welch, 2015). 


\section{Mll Macrothink}

Issues in Social Science

ISSN 2329-521X

2020, Vol. 8, No. 2

Technical feasibility analysis is the examination of the production processes involved and the engineering requirements of a project. The nature and capacity of plant and machinery to be installed are determined. Based on that, operating requirements in terms of quantity and quality of factor inputs such as raw materials, labour, water or electricity are then determined. The appraisal of sources of these key factor inputs forms part of the examination. Moreover, the location of the plant site is considered. The best choice for location is theoretically one that minimizes overall transport costs. In real life situations, however, factors other than considerations of minimizing costs may be involved - factors such as nearness to the investor's home state, availability of required infrastructural facilities or any industrial zoning policy of the government.

Economic analysis is the evaluation of the economic conditions that affect a project, an examination of the market for its product and a consideration of the factor of management. The prevailing fiscal, monetary and industrial policies of the government must be examined to determine how they affect a project in such respects as raw material sources, plant location, pollution or quality standards, and taxation rates. Some economies have definite income policies, specific guidelines on the capital and ownership structure of establishments, etc. These must be established in depth, as they are bound to influence the financial policy of a project as well its overall viability. In addition, market analysis involves an examination of the existing and potential market for the product to determine its volume, the prevailing price structure and marketing practices. The analysis should also be extended to the factor market for the project. The might be need to examine the price structure and payment terms for raw materials and other factor inputs. In terms of sequencing, market analysis ought to precede technical analysis, because some technical questions, such as plant capacity, product quality, raw material requirements and packaging are determined through market analysis. Finally, management analysis involves the examination of the type and number of each class of personnel required for the project and devises a suitable organization structure for carrying it out.

Financial analysis implies a comparison of the financial benefits of a project with the costs of its implementation. This would entail the translation of the estimated capital and operating requirements into financial costs, and the estimated benefits into financial revenue. The completed financial analysis of a project would theoretically reduce the project to a stream of cash flows (cash inflows and outflows), on the basis of which a final viability test can be conducted. The main focus of this review (of advanced capital budgeting techniques) is financial analysis dimension of project evaluation.

\subsection{Basic Techniques for Capital Budgeting}

Maximizing shareholders' wealth is the fundamental goal of managers in the theory of finance. It has been argued that maximizing shareholders' wealth is equivalent to maximizing the discounted cash flows provided by investment projects. We assume a world of certain cash flows, known discount rate, zero agency costs and frictionless markets, so that financial managers can separate investment decisions from individual shareholder preferences. All managers need to know are cash flows and the required market rate of return for projects of equivalent risk. 


\section{Mll Macrothink}

Six major problems face managers when they make investment decisions. First, they have to search out opportunities in the market place or new technologies. These are the basis of growth. The solution to this problem is outside the scope of the Theory of Finance. Second, the expected cash flows from the projects have to be estimated. Third, the discount rate to apply to the estimated cash flows should be determined. Fourth, the interrelationship between a contemplated project and the firm's existing portfolio of projects needs to be ascertained (cross-sectional links). Fifth, the independence between a project and the firm's future investments through their time- series links is a matter of critical strategic importance. And finally, the projects have to be evaluated according to sound decision rules. Investment decision rules are referred to as capital budgeting techniques.

The best capital budgeting technique will possess the following essential property: It will maximize shareholders' wealth. This essential property can be broken down into separate criteria:

All cash flows should be estimated

The cash flows should be discounted at the opportunity cost of funds

The technique should select from a set of mutually exclusive projects the one that maximizes shareholders' wealth

Managers should be able to consider one project independently from all others (this is known as the value-additivity principle)

The value-additivity principle implies that if we know the value of separate projects accepted by management, then simply adding their values, $\mathrm{Vj}$, will give us the value of the firm, $\mathrm{V}$. In mathematical terms, if there are $\mathrm{N}$ projects, then the value of the firm is:

$$
V=\sum V_{j}^{N}
$$

This is a particularly important point because it means that projects can be considered on their own merit without the necessity of looking at them in an infinite variety of combinations with other projects.

There are four widely used capital budgeting techniques namely: (1) the Capital Recovery (or Payback) Period (CRP), (2) the Accounting Rate of Return, (3) the Net Present Value (NPV), and (4) the Internal Rate of Return (IRR).

Other techniques include: (5) Discounted Payback (6) Time-adjusted Discounting (7) Profitability Index (PI) (8) Modified Internal Rate of Return (MIRR)

The net present value (NPV) model has been adjudged as that technique that is always consistent with shareholders' wealth maximization. Mathematically, 


$$
N P V=\sum_{t=1} N C F t /(1+k)^{t}-I_{0}
$$

Where NCFt is the net cash flow in time period t, I0 is the initial cash outlay, $\mathrm{k}$ is the firm's weighted average cost of capital, and $\mathrm{N}$ is the number of years in the project. The decision rule is to accept positive NPV projects only. If the projects contemplated are mutually exclusive, select the project with the greatest NPV.

On the other hand, the internal rate of return (IRR) on a project is the rate which equates the present value of the cash outflows and inflows. In other words, it is the rate that makes the computed NPV exactly zero. Mathematically, we solve for the rate of return where the NPV equals zero:

$$
\mathrm{NPV}=0 \stackrel{\mathrm{N}}{=} \underset{\mathrm{t}=1}{\mathrm{~N}} \mathrm{NCFt} /(1+\mathrm{IRR})^{\mathrm{t}}-\mathrm{I}_{0}
$$

or by interpolation of NPVs,

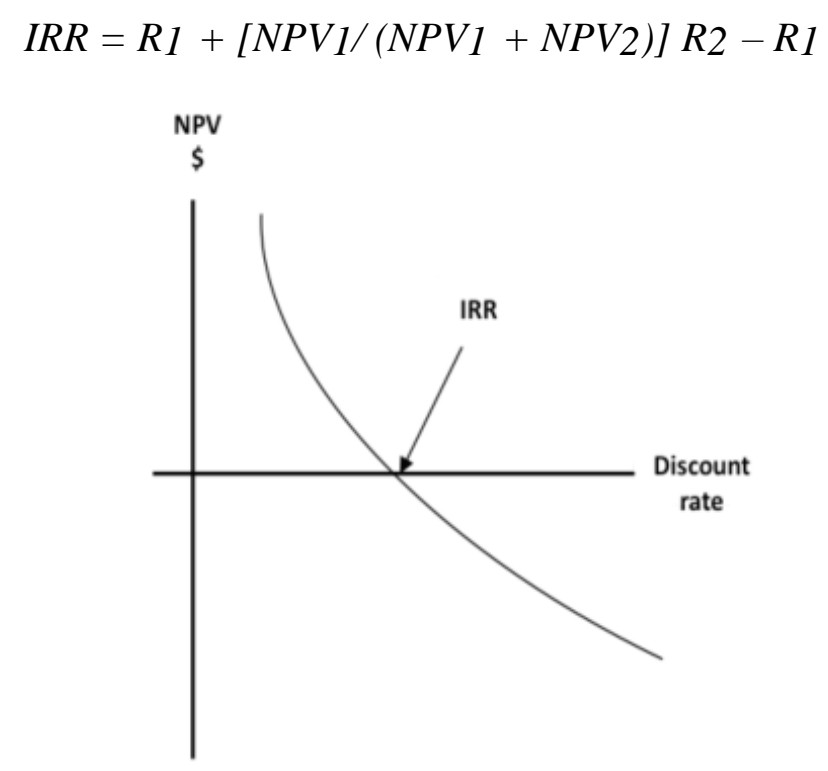

Figure 1. Net Present Value Profile

\subsection{Comparison of the NPV with the IRR}

The NPV and the IRR can favour conflicting project choices. Both techniques consider all cash flows and both use the concept of the time value of money in order to discount cash flows. We can recall that the market-determined opportunity cost of funds is the rate managers must use if they desire to maximize shareholders' wealth. Consequently, no other discount rate is appropriate. The first weakness of the IRR is that it does not discount at this opportunity cost of capital. Instead, it implicitly assumes that the time value of money is the IRR, since all cash flows are discounted at that rate. This implicit assumption has come to be called the reinvestment rate assumption. 
1). The Reinvestment Rate Assumption

The correct interpretation for the reinvestment rate is that it is really the same thing as the opportunity cost of capital. Both the NPV rule and the IRR rule make implicit assumptions about the reinvestment rate. The NPV rule assumes that shareholders can reinvest their money at the opportunity cost of capital. This is the reinvestment rate assumption consistent with shareholders' wealth maximization. However, the IRR rule assumes that investors can reinvest their money at the IRR for each project. Differential IRRs which may arise for projects of equivalent risk defies logic. Therefore, the IRR violates the second of the four properties mentioned earlier. It also violates the Fisher Separation Theorem.

2). The Value-Additivity Principle.

The fourth of the desirable characteristics of capital budgeting rules demands that managers be able to consider one project independently of all others. This is known as the value-additivity principle, and it implies that the value of the firm is equal to the sum of the values of each of its projects. A demonstration is provided in table 1 below. Projects 1 and 2 are mutually exclusive, and project 3 is independent of them.

Table 1. Illustration of Value-Additivity (Figures in N'millions)

\begin{tabular}{|c|c|c|c|c|c|c|}
\hline Year & Project 1 & Project 2 & Project 3 & PV Factor @ 10\% & $1+3$ & $2+3$ \\
\hline 2012 & $(100)$ & $(100)$ & $(100)$ & 1.000 & $(200)$ & $(200)$ \\
\hline 2013 & 0 & 225 & 450 & 0.909 & 450 & 675 \\
\hline 2014 & 550 & 0 & 0 & 0.826 & 550 & 0 \\
\hline
\end{tabular}

\begin{tabular}{|l|l|l|}
\hline Project & NPV @ 10\% & IRR \\
\hline 1 & 354.30 & $134.5 \%$ \\
\hline 2 & 104.53 & $125.0 \%$ \\
\hline 3 & 309.05 & $350.0 \%$ \\
\hline $1+3$ & 663.35 & $212.8 \%$ \\
\hline $2+3$ & 413.58 & $237.5 \%$ \\
\hline
\end{tabular}

If the value-additivity principle holds, we should be able to choose the better of the two mutually exclusive projects without having to consider the independent project. The NPVs of the three projects as well as their IRRs are also given in the table above. If we use the IRR rule to choose between projects 1 and 2, we would select project 1 . But if we consider combinations of projects, then the IRR rule would prefer projects 2 and 3 to projects 1 and 3. The IRR rule prefers project 1 in isolation but project 2 in combination with the independent project. In this illustration, the IRR does not obey the value-additivity principle. The implication for management is that it would have to consider all possible combinations of projects and choose the combination that has the greatest internal rate of return.

The NPV rule always obeys the value-additivity principle. Given that the opportunity cost of capital is $10 \%$, we would choose project 1 as being the best either by itself or in combination 
with project 3. Consequently, the value of the firm is the sum of the values of the projects.

3). Multiple Rates of Return

Still another difficulty with the IRR is that it can result in multiple rates of return if the cash flows change signs more than once. A classic example is the oil-well pump problem described in Copeland and Weston (1988:33-34). Table 2 below reproduces the associated incremental cash flows.

Table 2. Oil-Well Pump Incremental Cash Flows

\begin{tabular}{|l|l|}
\hline Year & Estimated Cash Flow (N'M) \\
\hline 2021 & $(1,600)$ \\
\hline 2022 & 10,000 \\
\hline 2023 & $(10,000)$ \\
\hline
\end{tabular}

If the opportunity cost of capital is $10 \%$, the NPV rule would reject the project because it has negative NPV at that rate. If we are using the IRR rule, the project has two IRRs, $25 \%$ and $400 \%$. Since both exceed the opportunity cost of capital, the project would probably be accepted.

Mathematically, the multiple IRRs are a result of Descartes' rule of signs, which implies that every time the cash flows change signs, there may be a new (positive, real) root to the problem solution. For the above example, the signs of the cash flows change twice. The IRR is the rate that causes the discounted values of cash flows to equal zero. Hence we solve the following equation for IRR:

$$
\begin{aligned}
& \mathrm{NPV}=0=(1600) /(1+\mathrm{IRR})^{0}+10,000 /(1+\mathrm{IRR})^{1}+(10,000) /(1+\mathrm{IRR})^{2} \\
& 0=\underline{(1600)(1+\mathrm{IRR})^{2}}+10,000(1+\mathrm{IRR})-10,000 \\
& 0=1,600(1+\mathrm{IRR})^{2} \\
& 0 . \mathrm{IRR})^{2}-10,000(1+\mathrm{IRR})+10,000
\end{aligned}
$$

This is clearly a quadratic equation and has two roots. It has the general form

$$
a x^{2}+b x+c=0
$$

and can be solved using the formula

$$
x=\frac{-b \pm \sqrt{ }\left(b^{2}-4 a c\right)}{2 a}
$$

In sum, the NPV avoids all the problems the IRR is heir to. It obeys value-additivity principle, correctly discounts at the opportunity cost of funds and most important, it is precisely the same thing as maximizing the shareholders' wealth.

\subsection{Cash Flows for Capital Budgeting Purposes}

Relevant cash flows should be ascertained for capital budgeting decisions given debt financing and taxes (Scholes, et al, 2015). In particular, some cash flows, such as interest 
paid on debt and repayment of principal on debt, should not be considered cash flows for capital budgeting purposes.

The following items are important notes in ascertaining relevant cash flows:

1) Initial cash outlay coming in time period zero.

2) Incremental working capital requirements: any increase in working capital investment is treated as cash flow because it reduces cash flow. It must come at the beginning of the year in which it is relevant. At the end of the project life, the same amount of working capital is treated as a cash inflow.

3) Running costs of raw materials, labour and overheads are important

4) Benefits, such as savings in operating costs and annual sales revenue.

5) Terminal, scrap or resale value of assets must come in as cash inflows at the end of the project's life.

6) Ignore sunk costs in cash flow estimations. Hence, sunk costs are money already spent or committed and therefore irrelevant to current investment decisions for example, cost of feasibility study, market study and consultancy fees.

7) Ignore interest payments and financing costs because they have already been incorporated in the project's discount rate. The underlying idea of discounting at the opportunity cost of funds is that projects undertaken by the firm must earn enough cash flow to provide the required rate of return to creditors, repayment of the face amount of debt, and payment of expected dividends to shareholders. This idea underlies concepts in the financial contracting literature (Roberts, 2015). Only when cash flows exceed these amounts will there be any gain in shareholders' wealth. When we discount cash flows at the weighted average cost of capital (WACC), this is exactly what we are saying. A positive NPV is achieved only after creditors and shareholders receive their expected risk-adjusted rates of return. In addition, when evaluating a project, it is important to use a cost of capital which is appropriate to the risk of the project. The existing WACC will therefore be appropriate as a discount rate if both:

$\checkmark \quad$ the new project has the same level of business risk as the existing operations. If business risk changes, required returns of shareholders will change, and hence WACC will change.

$\checkmark$ undertaking the new project will not alter the firm's gearing (financial risk). The values of equity and debt are the key components in the calculation of WACC, so if the values change, clearly the existing WACC will no longer be applicable.

$\checkmark$ Arising from the above point, the quadrant below captures the appropriate appraisal technique depending on the project's impact on the business and financial risks of the firm. 
Table 3. Quadrant Showing Appropriate Appraisal Technique Based on Project Risk Profile

\begin{tabular}{|l|l|l|l|}
\hline & \multicolumn{3}{|c|}{ BUSINESS RISK } \\
\hline & & Same & Different \\
\hline FINANCIAL & Same & Existing WACC & Risk-Adjusted WACC \\
\cline { 2 - 4 } RISK & Different & Use Adjusted Present Value (APV) & Use Adjusted Present Value (APV) \\
\hline
\end{tabular}

Source: Author's Review of Literature.

8) Depreciation: Ignore depreciation in cash flow estimation because it is an operating expense and not a cash flow expense.

9) Divisional payments: Ignore divisional payments because it is not a relevant element in the appraisal of projects.

10) Opportunity Costs: Identify and consider any opportunity cost i.e. existing resources of the firm that are made available should be included at their economic or opportunity cost.

11) Taxation Payments: Corporation tax rates must be applied to the project's operating cash flow and treated as cash outflow. Note that there are two possible assumptions about timing of cash flows namely:

$\checkmark \quad$ It could be assumed that tax payments occur same year as the profit or

$\checkmark \quad$ Tax payments occur one year after the profit year, i.e., one year time lag between earning the profit and payment of tax.

12) Capital Allowances: A company is entitled to claim capital allowances when it undertakes certain types of investments:

$\checkmark \quad$ It is claimed in lieu of depreciation

$\checkmark \quad$ It takes the form of written down allowance (WDA)/ written down value (WDV) which is granted at varying rates on assets.

13) Disposal of Assets: As a going concern, the assets originally bought by a company may be disposed off or sold at the end of the useful life of the project. This leads to the following:

$\checkmark$ Balancing Allowance: It arises when the written down value (WDV) of an asset at the time of sale is greater than the disposal value. This, in effect, means that there is a tax allowable loss on disposal and the company can therefore claim tax relief/savings.

$\checkmark$ Balancing Charge: It arises when the disposal value of an asset is greater than the WDV of an asset at the point of sale which gives rise to a taxable profit on disposal and the company therefore makes a tax payment.

14) Apportioned Fixed Overheads: This should be ignored because they represent costs that will be incurred anyway whether or not the project goes ahead.

In sum, the appropriate definition of cash flows for capital budgeting purposes is free operating cash flows minus taxes on free operating cash flows. 


\subsection{Profitability Index and Time-Adjusted Discounting}

PROFITABILITY INDEX: The profitability index (PI) of a project is the ratio of the sum of the present values of all its cash inflows to the sum of the present values of its cash outflows, i.e.,

$$
P_{I}=P V i / C i
$$

Where $\mathrm{P}_{\mathrm{I}}=$ profitability index of project $\mathrm{i}$

$\mathrm{PVi}=$ sum of present value of cash inflows from $\mathrm{i}$

$\mathrm{C}_{\mathrm{i}}=$ sum of present value of cash outflows of $\mathrm{i}$.

Decision rule: Similar decision rule with the NPV. You should accept only projects with PI>1; Reject projects with $\mathrm{PI}<1$; Rank and select among projects on the basis of their profitability indices.

TIME-ADJUSTED DISCOUNTING: One problem with the NPV method is that it does not explicitly consider constraints other than profitability in ranking projects. This, according to Okafor (1983, p. 230), could constitute a serious limitation, particularly in developing countries where the shortage of capital funds is a major constraint.

In situations like that, investment decisions become tied up with financing decisions and firms are compelled to consider not only the profitability, but also the liquidity of projects. Project liquidity, in this connection, is measured by the cash recovery potential of a project and not necessarily the ease of monetizing the assets.

Time-adjusted discounting is an evaluation process that adjusts the NPV of a project by its index of capital recovery. The model is used for ranking alternative projects. It is a four-stage evaluation process.

(a) The NPV rule is used to screen the alternatives into acceptable and unacceptable projects

(b) The capital recovery period for each acceptable alternative is determined

(c) The NPV of each acceptable project is divided by its capital recovery period to determine the present value of average annual incremental cash inflows expected within the capital recovery period.

(d) Projects are ranked on the basis of the annualized values of NPV determined in (C) above. The procedure is illustrated in table 3 below. 
Table 4. Ranking Projects By Time-Adjusted Discounting

\begin{tabular}{|c|c|c|c|}
\hline Periods & A & B & C \\
\hline 2016 & $(200)$ & $(200)$ & $(200)$ \\
\hline 2017 & 200 & 50 & 150 \\
\hline 2018 & 40 & 70 & 100 \\
\hline 2019 & 60 & 80 & 150 \\
\hline 2020 & 100 & 500 & 200 \\
\hline NPV & 128.2 & 304.85 & 1.5 years \\
\hline $\begin{array}{c}\text { Capital Recovery } \\
\text { Period (CRP) }\end{array}$ & 1 year & 3 years & 178.8 \\
\hline NPV/CRP & 128.2 & 101.62 & \\
\hline
\end{tabular}

Source: Author's computation.

It can be verified from table 4 that the time-adjusted discounting would rank the alternatives as follows: C, A, B. The NPV method, on the other hand, ranks them in the order B, C, A.

By accepting project $\mathrm{C}$ instead of $\mathrm{B}$, the firm would suffer some loss in present net worth. The apparent loss would, however, be compensated by the increased volume of funds generated in the early years of the life of project $\mathrm{C}$ which could be reinvested in other more attractive opportunities.

Since time-adjusted discounting reduces twice the significance of distant cash flows, it is an ideal method for analyzing projects that may, for a number of reasons, not live through their projected 'physical' and/or economic lives. The physical life of a project could be terminated because of political reasons (wars, nationalization, etc.). Even where the physical life is guaranteed, the economic life could be shortened by unforeseen changes in technology, changes in consumer taste, etc. Adverse changes in fiscal policy (such as a ban on the import of a crucial factor input) could also cause the unplanned obsolescence of a plant and cause the early abandonment of a project.

Consider what would happen if projects $\mathrm{B}$ and $\mathrm{C}$ were to be abandoned, for any reason, say after two years. The discounted cash flow from $\mathrm{C}$ would have paid off its initial cost of the project. The earlier the abandonment occurs, the greater the disparity in cost recovery. These considerations strengthen the merit of time-adjusted discounting in evaluating projects in developing countries where the shortage of capital is a serious constraint and projects are exposed to dangers of unplanned obsolescence due to political and economic factors (Okafor, 1983:231).

\subsection{The Modified Internal Rate of Return}

The IRR calculates the discount rate that would cause the project to break-even assuming it:

1) is the cost of financing the project

2) is the return that can be earned on all the returns earned by the project

Because of the problems with the standard IRR calculation namely its reinvestment rate 


\section{Macrothink}

Issues in Social Science

ISSN 2329-521X 2020, Vol. 8, No. 2

axiom, inconsistency with value-additivity and the possibility of more than a unique IRR or no IRR, a modification emerged known as the Modified Internal Rate of Return (MIRR). MIRR has been developed to counter the foregoing problems since it is unique and can deal with different borrowing and re-investment rates.

MIRR measures the economic yield of the investment under the assumption that any cash surpluses are reinvested at the firm's current cost of capital. Although the MIRR, like the IRR, cannot replace the NPV technique, it does give a measure of the maximum cost of finance that the firm could sustain and allow the project to remain worthwhile. For this reason, it gives a useful insight into the margin of error, or room for negotiation, when considering the financing of particular investment projects. The MIRR follows a three-stage calculation process:

Find the terminal value of the cash inflows from the project if invested at the company's reinvestment rate.

Find the present value of the cash outflows, discounted at the company's cost of funds.

The MIRR is then determined by taking the nth root of (TV Inflows/PV Outflows) and subtracting 1 (Note that $\mathrm{n}$ is the length of the project in years). The procedure is demonstrated in the following example.

A project requires an initial outlay of N24,000,000 and will generate annual cash flows as follows:

$\begin{array}{cc}\text { Year } & \text { Cash flow (N'000) } \\ 2021 & 7,800 \\ 2022 & 6,000 \\ 2023 & 4,200 \\ 2024 & 7,400 \\ 2025 & 9,200\end{array}$

The cost of capital is $10 \%$.

Required: a) Show the overall net cash position for the project if:

$\checkmark$ the company had a cost of capital equivalent to the IRR

$\checkmark$ and all cash flows earned were invested for the duration of the project at that rate

b) Assume now that funds can be borrowed at $10 \%$ whilst the reinvestment rate for positive cash flows is $12 \%$. What is the MIRR?

Solution: 
Table 5. NPV and IRR Computation

\begin{tabular}{|c|c|c|c|c|c|}
\hline Year & Cash Flow (N'000) & DF @ 10\% & PV (N'000) & DF @ 14\% & PV (N'000) \\
\hline 2020 & $(24,000)$ & 1.000 & $(24,000)$ & 1.000 & $(24,000)$ \\
\hline 2021 & 7,800 & 0.909 & $7,090.2$ & 0.877 & $6,840.6$ \\
\hline 2022 & 6,000 & 0.826 & $4,956.0$ & 0.769 & $4,614.0$ \\
\hline 2023 & 4,200 & 0.751 & $3,154.2$ & 0.675 & $2,835.0$ \\
\hline 2024 & 7,400 & 0.683 & $5,054.2$ & 0.592 & $4,380.8$ \\
\hline 2025 & 9,200 & 0.621 & $5,713.2$ & 0.477 & $4,774.8$ \\
\hline & & NPV & $1,967.80$ & & $(554.8)$ \\
\hline
\end{tabular}

Source: Author's computation.

This gives an IRR of:

$\operatorname{IRR}=10+[1,967.8 /(1,967.8+554.8)](14-10)=13.12 \%$

Using a spreadsheet, a more accurate IRR can be shown to be $13.07 \%$ and we can use this for demonstration purpose:

Table 6. Net Cash Position

\begin{tabular}{|c|c|c|c|c|}
\hline Year & Cash Inflow (N'000) & Invested For & Invested @ 13.07\% & PV (N'000) \\
\hline 2021 & 7,800 & 4 years & X $1.1307^{4}$ & $12,749.24$ \\
\hline 2022 & 6,000 & 3 years & X $1.1307^{3}$ & $8,673.48$ \\
\hline 2023 & 4,200 & 2 years & X $1.1307^{2}$ & $5,369.63$ \\
\hline 2024 & 7,400 & 1 year & X $1.1307^{1}$ & $8,367.18$ \\
\hline 2025 & 9,200 & - & & $9,200.00$ \\
\hline & & & & $44,359.53$ \\
\hline
\end{tabular}

Source: Author's computation.

The total amount invested at end of the project, the 2025 value (time 5 value) of the cost of the investment: $\mathrm{N} 24,000 \times(1.1307)^{5}=\mathrm{N} 44,356$ which matches the income from the returns. Or alternatively, time 0 value of the income from the returns $=44,360(1.1307)^{-5} \approx \mathrm{N} 24,000$. The net cash position for the project is therefore effectively zero, i.e., an IRR of $13.07 \%$ means that if the cost of borrowing and the return earned on investments were both $13.07 \%$, the project would break even.

To calculate the MIRR, we restate the project cash flows to be equivalent to an outflow at time 0 and a single inflow at the end of the project life (the 'terminal value'), using the assumed reinvestment rate. 


\section{1) Macrothink}

Table 7. MIRR

\begin{tabular}{|c|c|c|}
\hline Year & Cash flow @ time 0 (N'000) & Equivalent Cash flow @ 2017 (N'000) \\
\hline 2012 & $(24,000)$ & 12,273 \\
\hline 2013 & $7,800 \times 1.12^{4}$ & 8,430 \\
\hline 2014 & $6,000 \times 1.12^{3}$ & 5,268 \\
\hline 2015 & $4,200 \times 1.12^{2}$ & 8,288 \\
\hline 2016 & $7,400 \times 1.12$ & 9,200 \\
\hline 2017 & $9,200 \times 1$ & 43,459 \\
\hline & & \\
\hline
\end{tabular}

Source: Author's computation.

Thus, what is the IRR of a cash outflow of N24,000 at time 0 followed by an inflow of N43,459 at time 5?

$\mathrm{N} 43,459 /(1+\mathrm{r}) 5=24,000$

$\mathrm{R}=(43,459 / 24,000)^{1 / 5}-1=0.126$.

So the MIRR is $12.6 \%$. This is therefore the return on the project.

Since the return on the project is higher than the cost of finance, the project should be accepted.

An alternative formula for deriving the MIRR is given as:

$$
1+M I R R=\left(1+r_{O}\right)[P V R / P V I]^{1 / n}
$$

where

$\mathrm{PVR}=$ the present value of the "return phase" of the project

PVI = the present value of the "investment phase" of the project.

ro $\quad=$ the firm's cost of capital.

\subsection{Projects With Different Lives}

Mutually exclusive projects with unequal economic lives present peculiar problems of choice. The solution to the problem is demonstrated by the use of the NPV technique assuming the projects are replicated indefinitely at constant scale. Mathematically, NPV of the resulting perpetuity is

$$
N P V(N, \infty)=N P V(N)\left[(1+k)^{N} /(1+k)^{N}-1\right]
$$

Table 8. Example of Projects With Different Lives

\begin{tabular}{|c|c|c|c|c|}
\hline Year & 2021 & 2022 & 2013 & 2014 \\
\hline Project A & $(10,000)$ & 6,000 & 6,000 & \\
\hline Project B & $(10,000)$ & 4,000 & 4,000 & 4,750 \\
\hline
\end{tabular}


At a discount rate of 10\%, NPVs of projects A and B are N410 and N500 respectively. Project B would be preferred to A. However, we do not know the outcome at the end of the two-year life of A. So, we assume that the cash flows can be re-invested at the firm's opportunity cost of funds.

Given this axiom, the value of the two-year project, A, replicated at constant scale forever is

$$
\begin{gathered}
N P V(2, \infty)=N P V(2)\left[(1+0.10)^{2} /(1+0.10)^{2}-1\right]=(410)\left[1.1^{2} / 1.1^{2}-1\right]=410(1.21 / 0.21) \\
=N 2,360
\end{gathered}
$$

For Project B, the three-year project, we have

$$
N P V(3, \infty)=N P V(3)\left[(1+0.10)^{3} /(1+0.10)^{3}-1\right]=N 2,020
$$

When the cash flows are adjusted for different project lives, A provides greater wealth.

Another way of comparing the projects is to multiply the NPVs of the infinitely replicated projects by the opportunity cost of capital to obtain what is called the annual equivalent value, which is given mathematically as:

$$
\operatorname{KNPV}(N, \infty)=N P V(N)\left[k(1+k)^{N} /(1+k)^{N}-1\right]
$$

It is important to note that the annual equivalent rule is only appropriate for comparing projects with equivalent risk.

Moreover, the simple NPV rule can be applied to determine the optimal life, or duration, of a project. Applying the basic maximization principle in economics, the optimal duration occurs at the point where the NPV is maximized, which is equivalent to equality of the marginal rate of return and the opportunity cost of capital. The IRR rule, assuming replication with proportionately increasing scale, could give a good solution to the duration problem if the re-investment rate assumption is modified to re-investment at the firm's opportunity cost of capital. In sum, the NPV rule with constant scale replication gives the best solution to the optimal project life question (Copeland \& Weston, 1988, pp. 54-55).

\section{Capital Budgeting Techniques in Practice}

Following discussion of the basic techniques for investment appraisal, it is important to examine, from financial manager surveys, the capital budgeting techniques that are favoured in practice. Corporate capital budgeting (CB) and cost of capital estimation are among the most important decisions made by the financial manager. In this process, it is crucial that management use methods that result in shareholders' wealth maximization. Over time, managers have used commonly taught capital budgeting models and cost of capital estimation procedures; however, the use of models may not always align with what is taught in collegiate finance. The fast pace of change in digital technologies, the globalization of business, expanding expectations and the tail winds of the 2007-

2009 global financial crisis and European debt crisis are among the many factors that make the current business environment particularly challenging and thus, render simple CB techniques inappropriate for investment appraisal. Along these lines, a recent ACCA report 
(2016) reveals:

"Financial managers are going to need deeper technical knowledge of, and different approaches to, some areas of financial management, as well as mastery of a new financial management discipline. There are a diverse selection of 'emerging issues' where technical and communication skills that are lacking today will be vital by 2025-30. Included are understanding of: global trade and markets; Islamic finance; investment appraisal; alternative ways of raising funds; plus the knowledge of multiple languages, local tax and capital movement laws and business practices..." (ACCA, 2016:39).

The report further states:

"The focus on free cash flows will continue, so a standard definition of this and how to measure it is needed, rather than different companies taking different approaches. Views in the finance profession are polarized as to whether some financial models will continue to be useful. Some see a continuing need for calculations such as net present value (NPV), while others argue that as more non-quantifiable factors are involved in investment...valuation, decisions should be based less on NPV and similar financial models, and more on the balance of the entire portfolio, including intangibles such as trademarks, regional operating licences, strategic shift and brand strength...." And further stating that "Financial managers will need to provide reliable forward-looking forecasts based on understanding of the business and its environment (not just the figures)."

Graham (2011) has suggested the use of CFO surveys as a motivational tool to bridge the gap between the theory and practice of Corporate Finance.

\subsection{Survey on the Use of Capital Budgeting Techniques}

The research of Ryan and Ryan (2002), on capital budgeting methods utilized by Fortune 1000 companies, reveals the Net Present Value (NPV) as the most preferred technique. Andres, Fuente \& San Martin (2014) concur with respect to the Spanish market. Both the NPV and IRR are superior to other basic capital budgeting tools. Amongst the more advanced capital budgeting tools, sensitivity analysis and scenario analysis were the most popular tools. The results are displayed are displayed in tables 9 and 10 below. 


\section{$\triangle$ Macrothink}

Table 9. Comparison of Basic Capital Budgeting Tools

Response to the question: "Please classify how frequently your firm utilizes each of the following budgeting tools. "Often" would generally mean that you use this tool about $75 \%$ of the time, "sometimes" would refer to about 50\%, and "rarely" would mean about $25 \%$ of the time." The absolute percentages are in columns 3-7 and the cumulative percentages are in columns 8-10. Results are based on 205 responses by size of capital budget. All tools can be completed with basic Excel or other spreadsheet functions.

\begin{tabular}{|c|c|c|c|c|c|c|c|c|c|}
\hline \begin{tabular}{|c|} 
Capital \\
Budgeting Tool \\
(level of \\
technical \\
difficulty, \\
L=Low, \\
M=Medium, \\
H=High)*
\end{tabular} & $\begin{array}{c}\text { Size of } \\
\text { Capital } \\
\text { Budget (in } \\
\text { millions) }\end{array}$ & \begin{tabular}{|l|} 
Always \\
$(100 \%)$
\end{tabular} & $\begin{array}{l}\text { Often } \\
(75 \%)\end{array}$ & $\begin{array}{c}\text { Sometimes } \\
(50 \%)\end{array}$ & $\begin{array}{l}\text { Rarely } \\
(25 \%)\end{array}$ & $\begin{array}{c}\text { Never } \\
(0 \%)\end{array}$ & $\begin{array}{c}\text { Always or } \\
\text { Often } \\
(>=75 \%)\end{array}$ & $\begin{array}{c}\text { Always, } \\
\text { Often, or } \\
\text { Sometimes } \\
(>=50 \%)\end{array}$ & $\begin{array}{c}\text { Rarely or } \\
\text { Never } \\
(<=25 \%)\end{array}$ \\
\hline $\begin{array}{c}\text { Net Present } \\
\text { Value (NPV) } \\
* * *(\mathbf{L})\end{array}$ & $\begin{array}{c}\text { Less than } \\
\$ 100 \\
\text { Full } \\
\text { Sample }\end{array}$ & $\begin{array}{l}32.9 \% \\
49.8 \%\end{array}$ & $\begin{array}{l}52.6 \% \\
\mathbf{3 5 . 3 \%}\end{array}$ & $10.9 \%$ & $\begin{array}{l}1.3 \% \\
\mathbf{3 . 0 \%}\end{array}$ & $\begin{array}{l}0.0 \% \\
1.0 \%\end{array}$ & $\begin{array}{l}85.5 \% \\
85.1 \%\end{array}$ & $\begin{array}{l}98.7 \% \\
\mathbf{9 6 . 0 \%}\end{array}$ & $\begin{array}{l}1.3 \% \\
\mathbf{4 . 0 \%}\end{array}$ \\
\hline \begin{tabular}{|c|} 
Internal Rate \\
of Return \\
(IRR) \\
$* *($ L) \\
\end{tabular} & \begin{tabular}{|c|} 
Less than \\
$\$ 100$ \\
Full \\
Sample
\end{tabular} & \begin{tabular}{|l|}
$30.3 \%$ \\
$44.6 \%$
\end{tabular} & $\begin{array}{l}43.4 \% \\
32.2 \%\end{array}$ & $\begin{array}{l}21.1 \% \\
15.3 \%\end{array}$ & $\begin{array}{l}3.9 \% \\
6.4 \%\end{array}$ & $\begin{array}{l}1.3 \% \\
\mathbf{1 . 5 \%}\end{array}$ & $\begin{array}{l}73.7 \% \\
76.7 \%\end{array}$ & $\begin{array}{l}94.8 \% \\
\mathbf{9 2 . 1 \%}\end{array}$ & $\begin{array}{l}5.2 \% \\
7.9 \%\end{array}$ \\
\hline Payback ** (L) & \begin{tabular}{|c|} 
Less than \\
$\$ 100$ \\
Full \\
Sample
\end{tabular} & \begin{tabular}{|l|}
$26.0 \%$ \\
$19.4 \%$
\end{tabular} & $\begin{array}{l}37.7 \% \\
33.2 \%\end{array}$ & $\begin{array}{l}20.8 \% \\
21.9 \%\end{array}$ & $\begin{array}{l}13.0 \% \\
16.8 \%\end{array}$ & $\begin{array}{l}2.5 \% \\
8.7 \%\end{array}$ & $\begin{array}{l}63.7 \% \\
52.6 \%\end{array}$ & $\begin{array}{l}84.5 \% \\
74.5 \%\end{array}$ & $\begin{array}{l}15.5 \% \\
25.5 \%\end{array}$ \\
\hline $\begin{array}{l}\text { Discounted } \\
\text { Payback (L) }\end{array}$ & \begin{tabular}{|c|} 
Less than \\
$\$ 100$ \\
Full \\
Sample \\
\end{tabular} & $17.6 \%$ & $28.3 \%$ & $20.3 \%$ & $\begin{array}{l}20.3 \% \\
21.1 \%\end{array}$ & $\begin{array}{l}13.5 \% \\
22.2 \%\end{array}$ & $\begin{array}{l}45.9 \% \\
37.6 \%\end{array}$ & $66.2 \%$ & $\begin{array}{l}33.8 \% \\
43.3 \%\end{array}$ \\
\hline $\begin{array}{l}\text { Profitability } \\
\text { Index* (L) }\end{array}$ & \begin{tabular}{|c|} 
Less than \\
$\$ 100$ \\
Full \\
Sample \\
\end{tabular} & $5.9 \%$ & $22.2 \%$ & $25.0 \%$ & $20.8 \%$ & $\begin{array}{l}29.2 \% \\
34.2 \%\end{array}$ & $25.0 \%$ & $50.0 \%$ & $\begin{array}{l}50.0 \% \\
56.1 \%\end{array}$ \\
\hline $\begin{array}{c}\text { Accounting } \\
\text { Rate of } \\
\text { Return } *(\mathrm{~L})\end{array}$ & \begin{tabular}{|c|} 
Less than \\
$\$ 100$ \\
Full \\
Sample
\end{tabular} & $\begin{array}{l}8.2 \% \\
5.3 \%\end{array}$ & $5.5 \%$ & $24.6 \%$ & $\begin{array}{l}9.6 \% \\
16.4 \%\end{array}$ & $\begin{array}{l}52.1 \% \\
50.3 \%\end{array}$ & $\begin{array}{l}13.7 \% \\
14.7 \%\end{array}$ & $38.3 \%$ & $\begin{array}{l}61.7 \% \\
66.7 \%\end{array}$ \\
\hline $\begin{array}{c}\text { Modified IRR } \\
*(\mathrm{M})\end{array}$ & \begin{tabular}{|c|} 
Less than \\
$\$ 100$ \\
Full \\
Sample
\end{tabular} & $\begin{array}{l}0.0 \% \\
2.2 \%\end{array}$ & $\begin{array}{l}4.2 \% \\
7.1 \%\end{array}$ & $\begin{array}{l}14.1 \% \\
12.6 \%\end{array}$ & $\begin{array}{l}25.4 \% \\
27.9 \%\end{array}$ & $\begin{array}{l}56.3 \% \\
50.3 \%\end{array}$ & $\begin{array}{l}.2 \% \\
9.3 \%\end{array}$ & $\begin{array}{l}18.3 \% \\
21.9 \%\end{array}$ & $\begin{array}{l}81.7 \% \\
78.1 \%\end{array}$ \\
\hline
\end{tabular}

Note. $* * *$ is $\chi 2$ significant within the specific capital budgeting method at the .01 level,

** is $\chi^{2}$ significant within the specific capital budgeting method at the .05 level, and

$*$ is $\chi 2$ significant within the specific capital budgeting method at the .10 level.

Source: Ryan and Ryan (2002). 
Table 10. Relative Usage of Various Supplementary Capital Budgeting Tools

Response to the question: "Please classify how frequently your firm utilizes each of the following budgeting tools. "Often" would generally mean that you use this tool about $75 \%$ of the time, sometimes" would refer to about $50 \%$, and "rarely" would mean about $25 \%$ of the time." The absolute percentages are in columns 2-6 and the cumulative percentages are in columns 7-9. Results are based on 205 responses.

\begin{tabular}{|c|c|c|c|c|c|c|c|c|}
\hline $\begin{array}{c}\text { Supplemental } \\
\text { Capital Budgeting } \\
\text { Tools* } \\
\text { (level of } \\
\text { technical }\end{array}$ & $\begin{array}{l}\text { Always } \\
(100 \%)\end{array}$ & $\begin{array}{l}\text { Often } \\
(75 \%)\end{array}$ & $\begin{array}{c}\text { Sometimes } \\
(50 \%)\end{array}$ & $\begin{array}{l}\text { Rarely } \\
(25 \%)\end{array}$ & $\begin{array}{c}\text { Never } \\
(0 \%)\end{array}$ & $\begin{array}{l}\text { Always or } \\
\text { Often } \\
(>=75 \%)\end{array}$ & $\begin{array}{c}\text { Always, } \\
\text { Often, or } \\
\text { Sometimes } \\
(>=50 \%)\end{array}$ & $\begin{array}{c}\text { Rarely or } \\
\text { Never } \\
(<=25 \%)\end{array}$ \\
\hline \multicolumn{9}{|l|}{$\begin{array}{c}\text { difficulty, L=Low, } \\
\text { M=Medium, } \\
\text { H=High) }\end{array}$} \\
\hline $\begin{array}{c}\text { Sensitivity } \\
\text { Analysis (M) }\end{array}$ & $20.5 \%$ & $44.6 \%$ & $20.0 \%$ & $4.1 \%$ & $10.8 \%$ & $65.1 \%$ & $85.1 \%$ & $14.9 \%$ \\
\hline $\begin{array}{c}\text { Scenario } \\
\text { Analysis (M) }\end{array}$ & $10.5 \%$ & $31.1 \%$ & $25.3 \%$ & $12.1 \%$ & $21.1 \%$ & $41.6 \%$ & $66.8 \%$ & $33.2 \%$ \\
\hline $\begin{array}{c}\text { Inflation } \\
\text { Adjusted } \\
\text { Cash } \quad \text { Flows } \\
(\mathrm{M}) \\
\end{array}$ & $12.0 \%$ & $19.4 \%$ & $15.2 \%$ & $25.1 \%$ & $28.3 \%$ & $31.4 \%$ & $46.6 \%$ & $53.4 \%$ \\
\hline \begin{tabular}{c}
\multicolumn{2}{c}{ Economic } \\
Value Added \\
$($ EVA) $(\mathrm{M}$ \\
\end{tabular} & $12.0 \%$ & $18.8 \%$ & $23.0 \%$ & $19.9 \%$ & $26.2 \%$ & $30.9 \%$ & $53.9 \%$ & $46.1 \%$ \\
\hline $\begin{array}{l}\text { Incremental } \\
\text { IRR (M) }\end{array}$ & $8.5 \%$ & $19.1 \%$ & $19.7 \%$ & $16.5 \%$ & $50.3 \%$ & $27.7 \%$ & $47.3 \%$ & $52.7 \%$ \\
\hline $\begin{array}{c}\text { Simulation } \\
(\mathrm{H})\end{array}$ & $3.1 \%$ & $16.2 \%$ & $17.8 \%$ & $27.2 \%$ & $35.6 \%$ & $19.4 \%$ & $37.2 \%$ & $62.8 \%$ \\
\hline $\begin{array}{c}\text { Market Value Added } \\
\text { (MVA) (M) }\end{array}$ & $3.7 \%$ & $11.2 \%$ & $18.1 \%$ & $26.6 \%$ & $40.4 \%$ & $14.9 \%$ & $33.0 \%$ & $67.0 \%$ \\
\hline PERT/CPM (M) & $1.1 \%$ & $7.1 \%$ & $22.8 \%$ & $26.1 \%$ & $42.9 \%$ & $8.2 \%$ & $31.0 \%$ & $69.0 \%$ \\
\hline $\begin{array}{l}\text { Decision Tree } \\
(\mathrm{M})\end{array}$ & $1.1 \%$ & $6.8 \%$ & $23.2 \%$ & $33.7 \%$ & $35.3 \%$ & $7.9 \%$ & $31.1 \%$ & $68.9 \%$ \\
\hline $\begin{array}{c}\text { Complex } \\
\text { mathematical } \\
\text { models }(\mathrm{H}) \\
\end{array}$ & $1.1 \%$ & $6.5 \%$ & $13.5 \%$ & $22.2 \%$ & $56.8 \%$ & $7.6 \%$ & $21.1 \%$ & $78.9 \%$ \\
\hline $\begin{array}{c}\text { Linear } \\
\text { Programming } \\
(\mathrm{H}) \\
\end{array}$ & $0.0 \%$ & $5.4 \%$ & $11.4 \%$ & $23.2 \%$ & $60.0 \%$ & $5.4 \%$ & $16.8 \%$ & $83.2 \%$ \\
\hline $\begin{array}{c}\text { Option } \\
\text { Pricing Model } \\
(\mathrm{H}) \\
\end{array}$ & $0.0 \%$ & $5.3 \%$ & $15.5 \%$ & $26.7 \%$ & $52.4 \%$ & $5.3 \%$ & $20.9 \%$ & $79.1 \%$ \\
\hline $\begin{array}{l}\text { Real Options } \\
(\mathrm{H})\end{array}$ & $0.5 \%$ & $1.1 \%$ & $9.7 \%$ & $23.2 \%$ & $65.4 \%$ & $1.6 \%$ & $11.4 \%$ & $88.6 \%$ \\
\hline
\end{tabular}

Source: Ryan and Ryan (2002). 


\section{MIl Macrothink}

Brief description of supplementary Capital Budgeting tools:

(1) Sensitivity analysis allows for the change in one input variable at a time, such as sales or cost of capital, to see the change in NPV. Please see Hovakimian (2009) for a theoretical analysis.

(2) Scenario analysis allows for the change in more than one variable at a time, including probabilities of such changes, to see the change in NPV.

(3) Inflation Adjusted Cash Flows adjusts expected future cash flows by an estimated inflation factor.

(4) Economic Value Added (EVA) measures managerial effectiveness in a given year or period (net operating profit after taxes - after tax cost of capital required to support operations)

(5) Incremental IRR is the IRR of the difference in cash flows of two comparison projects; commonly used in replacement decisions

(6) Simulation is a method for calculating the probability distribution of possible outcomes.

(7) Market Value Added (MVA) is the market value of equity - equity capital supplied by shareholders.

(8) PERT/CPM is the analysis and mapping of the most efficient financial decision.

(9) Decision trees are graphical illustrations used to model a series of sequential outcomes, along with their associated probabilities.

(10) Complex mathematical models a general term inclusive of various option pricing model techniques, complex real options, and firm specific proprietary models and methods.

(11) Linear programming identifies a set of projects that maximizes NPV subject to constraints (such as maximum available resources)

(12) Option pricing model include either binomial option pricing model or the Black-Scholes option pricing model, the latter used by firms such as Merck with high R\&D expenditures and relatively few, albeit large positive NPV investments.

(13) Real options include the opportunity for expansion, contraction, or abandonment of a capital project before the end of its life.

Both option pricing and real options techniques facilitate the integration of corporate financial objectives with organizational strategy and strengthen links with stakeholders' expectations and associated risks. The important survey papers in this area include Smit and Ankum (1993), McDonald (2006), Rigopoulous (2014) and Markovics (2016).

Graham and Harvey (2001) and Coleman, Maheswaran, and Pinder (2010) reveal similar results in terms of the dominance of the NPV and IRR over other tools. The most interesting results come from examining the responses conditional on firm and executive characteristics. Large firms are significantly more likely to use NPV than small firms. There is no difference 
in techniques used by growth and non-growth firms. Highly levered firms are significantly more likely to use NPV and IRR than firms with small debt ratios. This is not just an artifact of firm size. In unreported analysis, they find a significant difference between high- and low-leverage small firms as well as high- and low-leverage large firms. Interestingly, highly levered firms are also more likely to use sensitivity and simulation analysis. Perhaps because of regulatory requirements, utilities are more likely to use IRR and NPV and perform sensitivity and simulation analyses. In addition, executive characteristics could be critical to the choice of technique. They find that CEOs with MBAs are more likely than non-MBA CEOs to use net present value, but the difference is only significant at the $10 \%$ level. [Graham, Harvey and Puri (2012) present more recent evidence on the link between managerial attitudes and corporate behavior]. Elsas, Flannery, and Garfinkel (2014) is another important paper on the leverage connection to the capital budgeting decision.

Moreover, Graham and Harvey (2001; hereinafter G\&H) find that firms that pay dividends are significantly more likely to use NPV and IRR than are firms that do not pay dividends. This result is also robust to the analysis by size. Public companies are significantly more likely to use NPV and IRR than are private corporations. As their correlation analysis indicates, many of these attributes are correlated. For example, private corporations are also smaller firms.

Other than NPV and IRR, the payback period is the next most frequently used capital budgeting technique. This is surprising because financial textbooks have lamented the shortcomings of the payback criterion for decades. (Payback ignores the time value of money and cash flows beyond the cutoff date; the cutoff is usually arbitrary.) Small firms use the payback period almost as frequently as they use NPV or IRR. In untabulated analysis, they find that among small firms, CEOs without MBAs are more likely to use the payback criterion. The payback is most popular among mature CEOs. For both small and large firms, we find that mature CEOs use payback significantly more often than younger CEOs in separate examinations. Payback is also frequently used by CEOs with long tenure. Few firms use the discounted payback, a method that eliminates one of the payback criterion's deficiencies by accounting for the time value of money. An Australian example is provided in Coleman (2007).

It is sometimes argued that the payback approach is rational for severely capital constrained firms: if an investment project does not pay positive cash flows early on, the firm will cease operations and therefore not receive positive cash flows that occur in the distant future, or else will not have the resources to pursue other investments during the next few years. G\&H do not find any evidence to support this claim because they find no relation between the use of payback and leverage, credit ratings, or dividend policy. Their finding that payback is used by older, longer-tenure CEOs without MBAs instead suggests that lack of sophistication is a driving factor behind the popularity of the payback criterion.

In summary, compared to previous research, the survey results suggest increased prominence of NPV as an evaluation technique. In addition, the likelihood of using specific evaluation techniques is linked to firm size, firm leverage, and CEO characteristics. In particular, small 
firms are significantly less likely to use NPV. They are also less likely to use supplementary sensitivity and VaR analyses.

One of the interesting implications of capital budgeting is that the NPV of a project is equal to the expected increase in shareholders' wealth. This means that the moment a firm publicly reveals that it has undertaken a positive NPV project, the market price of the firm's stock should increase by the project's NPV, even though no cash inflows from the project have yet been received. The theory predicts that if managers accept positive NPV projects, any announcement of an increase in planned capital expenditures should result in an increase in the firm's stock price, whereas any announcement of a decrease will imply fewer positive NPV opportunities and result in a decline in the stock price.

\subsection{Constrained Capital Budgeting Problems}

Here, the capital budgeting decision is made where capital constraints exist, that is, in situations of capital rationing. Capital constraints can be imposed from within the firm, for example, as a disciplinary measure to reduce gearing during an economic downturn (Zhang, 1997) or imposed by the capital market (Campello, Giambona, Graham \& Harvey, 2011; 2012). Most economists would agree that strict capital constraints simply do not exist in the real world so long as capital markets are reasonably efficient (Guariglia, 2008). However, liquidity constraints could be experienced during a financial crisis and in the presence of market frictions. Hadlock and Pierce (2010) review some useful indices (or measures) of financial constraints.

Basically, there are two types of capital rationing namely single-period and multi-period. A single- period capital rationing refers to the situation where the funds constraint is experienced by the firm now but funds are expected to be freely available in later periods. In a multi-period situation, funds shortage or budget constraint is expected to persist over a number of periods or even indefinitely.

In addition, the projects can be categorized into two namely divisible and indivisible projects. Divisible projects are projects that are infinitely divisible so that the whole or fraction of the projects can be undertaken. On the other hand, indivisible projects are those which must be undertaken wholly or not undertaken at all. The table below summarizes the associated solution techniques based on the type of problem and category of project.

Table 11. Types of capital rationing problems and the associated solution techniques

\begin{tabular}{|l|l|l|l|l|}
\hline & $\begin{array}{l}\text { SINGLE _PERIOD } \\
\text { (DIVINIBLE } \\
\text { PROJECTS) }\end{array}$ & $\begin{array}{l}\text { SINGL-PERIOD } \\
\text { INDIVISIBLE } \\
\text { PROJECTS) }\end{array}$ & $\begin{array}{l}\text { MULTI-PERIOD } \\
\text { (DIVISIBLE PROJECTS) }\end{array}$ & $\begin{array}{l}\text { MULTI-PERIOD } \\
\text { INDIVISIBLE } \\
\text { PROJECTS) }\end{array}$ \\
\hline SOLUTION & PROFITABILITY & TRIAL \& ERROR & LINEAR & INTEGER \\
TECHNIQUE & INDEX & USING NPV RULE & PROGRAMMING \\
& & TECHNIQUE & \\
\hline
\end{tabular}


A great deal has been written on the topic of constrained capital budgeting. As a result of space constraints, we do not discuss the various approaches here. The interested reader is referred to Lorie and Savage (1955), Baumol and Quandt (1965), Myers (1972), Bierman and Smidt (2007a, 2007b), Guariglia (2008), Brunzell, Liljeblom, and Vaihekoski (2013), Markovics (2016) and Brealey, Myers, and Allen (2020) as an excellent set of references.

\section{Capital Budgeting Procedures under Inflation}

The major point emphasized here is the inflation impact on capital budgeting analysis. Inflationary factor can be incorporated in either the cash flows or the discount rate. Along the lines of cash flow adjustment for inflation, a distinction is usually made between nominal cash flows and real cash flows. Also, the discount rate can be adjusted to reflect either the nominal or real cost of capital. The transformation of discount rate from the real interest rate to the nominal interest rate of interest follows what has long been recognized as the Fisher effect, stated formally as:

$$
(1+r)(1+\varepsilon)=(1+k)
$$

Where $\mathrm{k}$ is the required rate of return in nominal terms, $\varepsilon$ is the anticipated inflation over the life of the project, and $r$ is the real rate of return. A major challenge in practice is the estimation of expected (future) inflation. This can be overcome if a reference is made to the term structure of interest rates. Also, the Treasury bill rate may serve as a proxy for near-term inflation.

To avoid conventional biases in capital budgeting under inflationary conditions, nominal cost of capital must be applied to discount nominal cash flows or real cost of capital applied to discount real cash flows in the DCF process. The whole essence is to ensure an efficient/ sound allocation of capital. Making the inflation adjustment does not always necessarily result in a negative NPV for the project, it simply results in a more accurate estimate of the net benefits from the project- positive or negative.

\section{The Term Structure of Interest Rates}

Two fixed-income instruments with similar (credit) risk profile but different tenor will have different yields to maturity. The relationship between the yield to maturity and the term to maturity of various fixed-income instruments is referred to as the term structure of interest rates. The graphical portrayal of the term structure is referred to as the yield curve. We are familiar with the four main theories of the term structure namely:

1) Expectations (or unbiased expectations) Theory

2) Liquidity Preference Theory

3) Market Segmentation Hypothesis

4) Preferred Habitat Hypothesis

The unbiased expectations theory holds that the forward interest rate (f2) is equal to the expected one-year (future) spot rate (2r1). Thus, a set of spot rates that is rising can be explained by the 
argument that the market opines that spot rates will be rising in the future and vice versa. The expectations theory implies that the only reason for an upward-sloping term structure is that investors expect short-term interest rates to rise; the only reason for a declining term structure is that investors expect short-term rates to fall. The expectations theory also implies that investing in a succession of short-term bonds gives exactly the same expected return as investing in long- term bonds. Mathematically, $(1+1 \mathrm{r} 1)(1+1 \mathrm{f} 2)=(1+1 \mathrm{r} 2)^{2}$, which can be conveniently interpreted to mean that the expected return from a maturity strategy must equal the expected return on a rollover strategy. In other words, a two-year investment can be thought of as earning the one- year spot rate for the first year and the extra return, or forward rate, for the second year [such that $\mathrm{f} 2=2 \mathrm{r} 1$ ]. The expectations theory fails to consider the fact that prices of long-duration bonds are more volatile than those of short-term bonds. This volatility of long-term bonds creates extra risk thus making short-term bonds to be preferred. The Liquidity preference theory (LPT) states that investors will demand a higher yield to compensate for the extra risk of long-term bonds. Thus, the forward rate will be higher than the expected spot rate because it embodies a liquidity premium (LP) and the term structure will be upward sloping more often than not. Even if future spot rates are expected to fall, the implied liquidity premium will offset the downward sloping effect of falling spot rates on the term structure. According to the LPT, $1 \mathrm{f} 2=2 \mathrm{r} 1+\mathrm{LP}$ and thus $(1+1 \mathrm{r} 1)(1+1 \mathrm{f} 2) \neq(1+1 \mathrm{r} 2)^{2}$. This inequality is the key to understanding how the liquidity preference theory explains the term structure (Sharpe, 1999:125). A third explanation for the determination of the term structure rests on the assumption that there is market segmentation. Various investors and borrowers are thought to be restricted by law, preference, or custom to certain maturities. Perhaps, there is market for short-term securities, intermediate term securities and a third for long-term securities. According to the market segmentation theory, spot rates are determined by supply and demand conditions in each market. With this theory, an upward-sloping term structure exists when the intersection of the supply and demand curves for shorter-term funds is at a lower interest rate than the intersection for longer-term funds. This situation could be due to either a relatively greater demand for longer-term funds by borrowers or a relatively greater supply of shorter-term funds by investors, or some combination of the two. A converse explanation holds for a downward-sloping term structure. Finally, a more moderate version of the market segmentation theory is embodied in the preferred habitat hypothesis which states that certain market segments attract an identifiable clientele of investors and borrowers to it. However, they are willing to leave their desired maturity segments if there are significant differences in yields between the various segments. These yield differences are determined by market forces within the segments.

As a result, as under the liquidity preference theory, the term structure under the preferred habitat hypothesis reflects both expectations of future spot rates and a risk premium. However, the risk premium under the preferred habitat argument does not necessarily rise directly with maturity but it is a function of the extra yield required to induce market participants to shift out of their preferred habitats.

Regardless of which theory of the term structure is correct, the fact that one-year forward rates are not constant is relevant for the capital budgeting decision. The cash flows estimated 
for each year should be discounted to the present, using the information revealed in the term structure of interest rates.

When the term structure is downward sloping, a firm that uses the long-term rate to discount all cash flows will tend to overestimate the NPVs of projects. Of course, when the term structure is upward sloping, the opposite bias exists. In addition, it is possible for the wrong project to be selected if the information given in the term structure is ignored.

It has been suggested that the term structure provides the best estimate of expected inflation (e.g., Fama, 2005). If so, a downward-sloping term structure implies that investors expect near- term inflation to be higher than long-term. An upward-sloping term structure (removing the liquidity premium) implies the opposite. If the firm's capital budgeting procedure discounts nominal cash flows (cum inflation) at market rates, the cash flow estimates should reflect inflation on a year-by-year basis.

\section{Conclusion}

This paper has attempted a review of capital budgeting techniques in theory and practice. The material captured is far from complete. The basic idea however lies in the evaluation of investment projects to determine their suitability on the basis of their financial attributes. An investment project is suitable if and only if it adds value to the shareholders' wealth. If all the possible investment projects cannot be undertaken, then the projects which add the greatest values to wealth should be undertaken. The major tool for determining this suitability is the NPV technique, sometimes supplemented by some other techniques. The key elements of the capital budgeting exercise include the correct definition of cash flows and the determination of the appropriate cost of capital. Risk and uncertainty factors introduce important extensions to the basic appraisal techniques. Recent evidence from Corporate America, United Kingdom and Australia reveals a continuous alignment and dominance of theoretical tools of NPV and IRR with capital budgeting practice based on the reported field surveys. Empirical research suggests that capital budgeting decisions will become more difficult over the coming years. The current operating environment charged by emerging digital technologies, forces of globalization, expanding stakeholder expectations, increased regulation and stronger governance, requires all CFOs to take a more rounded view within the business and a more global view of the business environment.

A major weakness of the DCF approaches lies in their failure to capture intangible assets and growth opportunities in capital budgeting situations. This weakness is especially more pronounced when the projects involved are not cash cows. Projects with substantial growth options could be better appraised using real-option valuation methods (McDonald, 2006). A fuller discussion of this aspect and related issues is a fertile ground for further research.

\section{References}

ACCA. (2016). Professional Accountants - the Future. A publication of the Association of Chartered Certified Accountants (ACCA).

Akintola-Bello, O. (1977). Capital Budgeting Decisions in the Nigerian Government 
Enterprises. Unpublished Ph.D. Thesis, University of Wales, Bangor.

Andres, P., Fuente, G., \& San Martin, P. (2014). Capital Budgeting Practices in Spain. Business Research Quarterly, 18, 37-56. https://doi.org/10.1016/j.brq.2014.08.002

Baumol, W. S., \& Quandt, R. E. (1965). Investment and Discount Rates Under Capital Rationing. Economic Journal, 75, 317-329. https://doi.org/10.2307/2229426

Bierman, H., \& Smidt, S. (2007a). The Capital Budgeting Decision (9th ed.). New York: Routledge.

Bierman, H., \& Smidt, S. (2007b). Advanced Capital Budgeting. New York: Routledge, 2007.

Brealey, R., Myers, S., \& Allen, F. (2020) Principles of Corporate Finance (13th ed.). McGrawHill Inc.

Brunzell, T., Liljeblom, E., \& Vaihekoski, M. (2013) Determinants of Capital Budgeting Methods and Hurdle Rates in Nordic Firms, Accounting and Finance, 53(1), 85-110. https://doi.org/10.1111/j.1467-629X.2011.00462.x

Campello, M., Giambona, E., Graham, J., \& Harvey, C. (2011). Liquidity Management and Corporate Investment During a Financial Crisis. Review of Financial Studies, 24, 1944-1979. https://doi.org/10.1093/rfs/hhq131

Campello, M., Giambona, E., Graham, J., \& Harvey, C. (2012). Access to Liquidity and Corporate Investment in Europe: The Credit Crisis of 2009. Review of Finance, 16, 323-346. https://doi.org/10.1093/rof/rfr030

Coleman, L. (2007). Risk and Decision Making By Finance Executives: A Survey Study. International Journal of Managerial Finance, 3, 108-124. https://doi.org/10.1108/17439130710721680

Coleman, L., Maheswaran, K., \& Pinder, S. (2010). Narratives in Managers' Corporate Finance Decisions. Accounting and Finance, 50(3), 605-633. https://doi.org/10.1111/j.1467-629X.2010.00343.x

Copeland, T. E., \& Weston, J. F. (1988). Financial Theory and Corporate Policy (3rd ed.). New York: Addison-Wesley Publishing.

Elsas, R., Flannery, M. J., \& Garfinkel, J. A. (2014). Financing major investments: Information about capital structure decisions. Review of Finance, 18(4), 1341-1386. https://doi.org/10.1093/rof/rft036

Elumilade, D. O., Asaolu, T. O., \& Ologunde, A. O. (2006). Capital Budgeting and Economic Development in the Third World: The Case of Nigeria. International Research Journal of Finance and Economics, 2, 1-17.

Fama, E. F. (2005). The Behavior of Interest Rates. Review of Financial Studies, 19, 359-379. https://doi.org/10.1093/rfs/hhj019

Fama, E. F., \& Miller, M. H. (1972). The Theory of Finance. Illinois: Dryden Press. 


\section{NI Macrothink}

Graham, J. R. (2011). Using CFO Surveys as a Motivational Tool to Teach Corporate Finance. Financial Review, 46, 193-205. https://doi.org/10.1111/j.1540-6288.2011.00296.x

Graham, J. R., \& Harvey, C. (2001). The Theory and Practice of Corporate Finance: Evidence from the Field. Journal of Financial Economics, 61, 187-243. https://doi.org/10.1016/S0304-405X(01)00044-7

Graham, J. R., Harvey, C., \& Puri, M. (2013). Managerial Attitudes and Corporate Action, Journal of Financial Economics, 109(1), 103-121. https://doi.org/10.1016/j.jfineco.2013.01.010

Graham, J. R., Hazarika, S., \& Narasimhan, K. (2011). Corporate Governance, Debt and Investment Policy During the Great Depression. Management Science, 57, 2083-2100. https://doi.org/10.1287/mnsc.1110.1415

Guariglia, A. (2008). Internal Financial Constraints, External Financial Constraints and Investment Choice: Evidence from a Panel of UK Firms. Journal of Banking and Finance, 32, 1795-1809. https://doi.org/10.1016/j.jbankfin.2007.12.008

Hadlock, C. J., \& Pierce, J. R. (2010). New Evidence on Measuring Financial Constraints: Moving Beyond the KZ Index. Review of Financial Studies, 23, 1909-1940. https://doi.org/10.1093/rfs/hhq009

Hovakimian, G. (2009). Determinants of Investment Cash Flow Sensitivity. Financial Management, 38, 161-183. https://doi.org/10.1111/j.1755-053X.2009.01032.x

Johnson, S. A. (2003). Debt Maturity and the Effects of Growth Opportunities and Liquidity Risk on Leverage. Review of Financial Studies, 16, 209-236. https://doi.org/10.1093/rfs/16.1.0209

Lorie, J. H., \& Savage, L. J. (1955). Three Problems in Capital Rationing. Journal of Business, 28, 229-239. https://doi.org/10.1086/294081

Markovics, K. S. (2016). Capital Budgeting Methods Used in Some European Countries and in the United States. Universal Journal of Management, 4(6), 348-360. https://doi.org/10.13189/ujm.2016.040604

McDonald, R. L. (2006). The Role of Real Options in Capital Budgeting: Theory and Practice, Journal of Applied Corporate $\quad$ Finance, $18, \quad 28-39$. https://doi.org/10.1111/j.1745-6622.2006.00085.x

Myers, S. C. (1972). A Note on Linear Programming and Capital Budgeting. Journal of Finance, 27, 89-92. https://doi.org/10.1111/j.1540-6261.1972.tb00622.x

Okafor, F. O. (1983). Investment Decisions: Evaluation of Projects and Securities. London: Cassell.

Rigopoulous, G. (2014). Real Options Adoption in Capital Budgeting: A Highlight of Recent Literature. Journal of Economics and Business Research, 20(2), 41-51.

Roberts, M. R. (2015). The role of dynamic renegotiation and asymmetric information in 


\section{Macrothink}

Issues in Social Science

ISSN 2329-521X 2020, Vol. 8, No. 2

financial contracting. Journal of Financial Economics, 116(1), 61-81. https://doi.org/10.1016/j.jfineco.2014.11.013

Ryan, P. A., \& Ryan, G. P. (2002). Capital Budgeting Practices of the Fortune 1000: How Have Things Changed? Working Paper Colorado State University.

Scholes, M., Wolfson, M., Erickson,M., Hanlon, M., Maydew, E., \& Shevlin, T. (2015). Taxes and Business Strategy: A Planning Approach (5th ed.). New Jersey: Prentice-Hall, EC.

Sharpe, W. F. (1999) Investments (6th ed.). N.J.: Prentice Hall Inc.

Smit, H. T. J., \& Ankum, L. A. (1993). A Real Options and Game-Theoretic Approach to Corporate Investment Strategy Under Competition. Financial Management, 22(3), 241-250. https://doi.org/10.2307/3665941

Welch, I. (2015) Corporate finance: An introduction (5th ed.). Pearson Education International.

Williamson, R., \& Yang J. (2013). Financial constraints, firm structure and acquisitions. Working Paper, Georgetown University.

Zhang, G. (1997). Moral Hazard in Corporate Investment and the Disciplinary Role of Voluntary Capital Rationing. Management Science, 43, 737-750. https://doi.org/10.1287/mnsc.43.6.737

\section{Copyright Disclaimer}

Copyright for this article is retained by the author(s), with first publication rights granted to the journal.

This is an open-access article distributed under the terms and conditions of the Creative Commons Attribution license (http://creativecommons.org/licenses/by/3.0/). 